COMO CITAR ESTE ARTÍCULO:

Porras, L. (2018). The limits of state labour law: It's inability to protect the working poor in Bogotá. Revista de Antropología y Sociología: VIRAJES, 20(2). 13-34. DOI: 10.17151/rasv.2018.20.2.2

\title{
The limits of state labour law: it's inability to protect the working poor in Bogotá
}

\section{LAURA PORRAS*}

Recibido: 16 de febrero de 2018

Aprobado: 1 de abril de 2018

Artículo de Reflexión

\footnotetext{
* Abogada con Especialización en Gestión Pública y Derecho Administrativo y Maestría en Derecho de la Universidad de los Andes. Ph.D en Derecho de la Universidad de Ottawa. Profesora de Carrera de la Universidad del Rosario. E-mail: laura.porras@urosario.edu.co. 누 ORCID: 0000-0001-8146-6934. Google Scholar
} 


\begin{abstract}
Using qualitative methodologies, I conducted research with one group of vulnerable workers (whom I refer to as street rebuscadores) in Bogotá, to study how both State and non-State legal regimes interact to influence their productive strategies. Following a legal pluralist approach, I concluded that as a social group engaging in regulatory activities, street rebuscadores are situated in a semiautonomous social field generating internal normative rules, but that is also vulnerable to rules from the larger social matrix in which it is situated. Within that semi-autonomous social field, the vulnerability of street rebuscadores is legally constructed and accentuated by the State, and existing regulatory frameworks are perpetuating and reproducing their condition, although not without resistance. In this paper, I will focus exclusively on labour law, to discuss a series of reasons that lead me to conclude that State labour law is unable to penetrate the semiautonomous social field of street rebuscadores, and therefore, unable to protect those workers most in need.
\end{abstract}

Key words: glean, vulnerable workers, informality, labor law.

\title{
Los límites del derecho laboral: su inhabilidad para proteger a algunos de los trabajadores más pobres de Bogotá
}

\section{Resumen}

El presente texto se basa en los resultados parciales de una investigación que realicé con un grupo de trabajadores vulnerables (a los que me refiero como rebuscadores callejeros) en Bogotá. El objetivo general de la investigación era estudiar la interacción entre distintos regímenes legales estatales y no estatales y su influencia en las estrategias productivas de los rebuscadores. Usando los lentes teóricos del pluralismo jurídico, concluí que los rebuscadores callejeros se ubican en un campo social semiautónomo que genera reglas normativas internas, pero que también es vulnerable a las reglas de la matriz social más amplia en la que se encuentran situados. Dentro de ese campo social semiautónomo, la vulnerabilidad de los rebuscadores callejeros está legalmente construida y acentuada por el Estado, y los marcos regulatorios existentes están perpetuando y reproduciendo su condición, aunque no sin resistencia. En éste documento, me centraré exclusivamente en el derecho laboral, para discutir una serie de razones que me llevan a concluir que el derecho laboral no penetra el campo social semiautónomo de los rebuscadores callejeros, y por lo tanto, no protege a trabajadores particularmente vulnerables.

Palabras clave: rebusque, trabajadores vulnerables, informalidad, derecho laboral. 


\section{Introduction}

y doctoral dissertation is about street rebuscadores
(street vendors, recyclers, street sex workers, etc.,) who
are looking for a way to make a living and survive. I am talking approximately about 82,000 people in Bogotá and 818,000 people in Colombia (National Department of Statistics of Colombia [DANE], 2015), who share the following five common characteristics: 1) they identify themselves as self-employed or family workers, 2) they conduct their work mainly in the street or other public spaces, 3) they report that this work occupies most of their time, 4) they are affiliated to the subsidized health care system, and 5) their highest educational degree (if obtained) is high school.

Using both quantitative and qualitative methodologies, including eighteen months of fieldwork in the neighbourhoods of Ciudad Bolívar and Suba in Bogotá (Sept 2012 to Jan 2014), I characterized the social grouping that I refer to as street rebuscadores elsewhere (Porras, 2018). After doing that, my aim was to analyse how both State and non-State laws interact to influence their productive strategies. To do that, I relied on the literature on legal pluralism (Fitzpatrick, 1984; Engle Merry, 1988; Griffiths, 1986; De Sousa Santos 1987, 2002, 2004, 2005, De Sousa Santos \& Rodriguez, 2005; Teubner, 1997; Tamanaha, 2000 amongst others), and more specifically on the concept of the semi-autonomous social field developed by Sally Falk Moore (Moore, 1973, 2005). Falk Moore's proposal is to take the "small field observable to an anthropologist" and to study it

in terms of its semi-autonomy - the fact that it can generate rules and customs and symbols internally, but that it is also vulnerable to rules and decisions and other forces emanating from the larger world by which it is surrounded. (Moore, 1973, p. 720)

I argue that as a social group engaging in regulatory activities, street rebuscadores are situated in a semi-autonomous social field generating internal normative rules, but this field is also vulnerable or influenced by rules from the larger social matrix in which it is situated. As a researcher, however, my job is not only to posit the existence of multiple legal spheres, but most importantly, to develop hypotheses concerning the relationships between them. In my doctoral dissertation I presented specific hypotheses about the ways in which both State and non-State laws interact to influence the productive strategies of street rebuscadores (Porras, 2108). I considered three regulatory fields with different levels and layers of interactions 
(State constitutional law, labour law and derecho de policía). My general argument was that street rebuscadores' vulnerability is legally constructed and accentuated by the State. In this paper, I will limit myself to discuss State labour law's inability to penetrate the semi-autonomous social field of street rebuscadores. ${ }^{1}$

\section{State labour law is unable to penetrate the semi- autonomous social field of street rebuscadores}

My hypothesis is based on a series of reasons that I will state as follows. First, State labour law it is rarely applicable since most street rebuscadores are self-employed and dependent on multiple parties. Secondly, even when applicable, street rebuscadores generally lack the cultural and economic capital required for the adjudication of their rights to be successful. Thirdly, the State is not interested in facilitating the enforcement of labour law in the applicable cases. Fourthly, even if it were, internal rules regarding labour relations are situated in relation of superior power to external rules and therefore deflect the operation of external law in the rare cases that could apply. Fifthly, after the tutela was created in 1991, labour disputes regarding street rebuscadores are more often translated as constitutional disputes litigated in the constitutional jurisdiction. And finally, often labour law is only called upon exceptionally by street rebuscadores, who do not necessarily hope to win the legal case, but who strategically use it to demonstrate strength through their alleged knowledge of the external State legal system. I will explain further each of these propositions.

\section{State Labour law is rarely applicable in the case of street rebuscadores}

State labour law is rarely applicable since most street rebuscadores are self-employed and dependent on multiple parties, which theoretically situates them outside the realm of labour law. After the Second World War, most western societies adopted regulation around the protection of a Standard Employment Relationship (SER) which is defined by a fulltime continuous job, supported on three central pillars: "employee status (i.e. bilateral employment relationship), standardized working time

\footnotetext{
${ }^{1}$ The content of this paper is based on part of my unpublished PhD dissertation. See Porras 2018. A preliminary version of the argument was published in Spanish in the book "Economía popular desde abajo." See: Porras 2017.
} 
(normal daily, weekly, and annual hours), and continuous employment (permanency)" (Vosko, 2010, p. 51). Regulation focused on wage-earners (especially industrial workers) who, possessing neither the capital nor the means of production, earned their living by selling their labour. Those wage-earners, also known to be part of the proletariat, were -and still arecommonly associated with the poorest class of working people.

However, as Vosko's analysis confirms, since the neoliberal era (post-1980 period), the SER has been increasingly eclipsed by 'nonstandard' forms of employment, such as part-time, fixed-term, temporary agency work and self-employment (Vosko, 2010). To address the situation, legislators in both developed and developing countries have tried to stretch State labour law drafted to protect the parties involved in a standard employment relationship (SER) to cover other types of 'non-standard' forms of employment. However, only workers in situations closely resembling the employment relationship received labour protection (Vosko, 2010). For example, the ILO Convention on part-time work (1994) limited its scope to permanent part-time wage-earners, excluding the self-employed as well as those engaged on temporary or casual bases. As a result, it neglected not only the most sizeable segment of part-time employees (casuals) but also, those who are worst off. As for the regulation on the precarious selfemployed, the ILO Recommendation on the Employment Relationship (2006) protected only dependent workers (those without a contract of employment but who depended mainly on a single client), excluding the vast majority who worked for more than one client (Vosko, 2010).

In Colombia most street rebuscadores are self-employed and dependent on multiple parties, which theoretically situates them in the commercial sphere and not in the realm of labour law. But are they really part of the commercial sphere? Do they see themselves as businessmen/ women? I talked to many rebuscadores about the issue, but maybe the best answer was given to me by Rosa (52 years old), mother of nine, who works approximately 10 to 14 hours a day as a recycler:

Rosa: A business woman? (¿una empresaria?), like the people who work or own companies or corporations or stuff? No way... come on! You know I earn my money with the sweat of my forehead (con el sudor de mi frente). I was destined to be a worker, to work. I came to this world with nothing and will probably leave the same way. Plus, we were born women... we were born to bring children to this world. I bet you know some businesspeople... I imagine them waking up in the morning with money in their pockets figuring out what to do next. Ha! No... not me. I wake up with empty pockets and go to rebuscármela. You've seen me, you know. Remember how you felt 
exhausted (mamada) after walking with me for a while? Remember? That's the life of a worker. We don't wake up to eat and drink. We arrive exhausted. Plus, I have 9 kids' right? I'm no businesswoman Laurita. I was born like the ox that plows the earth.

I thought Rosa was right. Business entrepreneurs are supposed to possess at least some capital or means of production to justify their exclusion from labour-related regulatory schemes. In fact, the term businessperson is usually used to refer to the founder, the owner, or the majority shareholder of a business, or to describe a high-level executive who does everyday running and management. Rosa described herself as an "ox" born to "plow the earth." She used an insightful metaphor that brings to mind images of endurance, honesty, diligence, hard work, hardships and difficulties. In fact, the image of an ox plowing the earth is incredibly similar to the image I have of Rosa pulling her recycling cart with the strength of her shoulders. At least intuitively, she brings to my mind the image of a worker, not of a business entrepreneur.

In Colombia, the three intrinsic elements of a labour law contract are: the personal rendering of services by the worker, an accorded salary for such services, and a relationship of subordination of the employee to the employer (article 23 of the Labor Code). The jurisprudential interpretation of the elements pertaining to the labour relationship centers its attention on the element of subordination. The Supreme Court of Justice interpreted the element of subordination as "the legal possibility that the employer has to give orders and instructions at any time and in the correlative obligation of the worker to comply" ${ }^{\prime 2}$. The Court makes clear that there is a difference between subordinated and independent work ${ }^{3}$. The benefits derived from a labour law contract are only applicable to subordinated work. Subordination, therefore, becomes the litmus test for the entrance or exit into the labor law realm.

In the case of Rosa, subordination does not exist, because she does not have an employer who gives her orders. Therefore, she is not part of a labour contract. She should make contributions to the social security system as an independent worker, but since the law assumes that independent workers are business entrepreneurs with economic capacity, the minimum contribution required of the independent worker who earns a minimum wage in 2017 is 210,400 pesos (Resolución 5858 of 2016). That could be

\footnotetext{
${ }^{2}$ See: Supreme Court of Justice, ruling issued the $21^{\text {st }}$ of February, 1984. Also see, Supreme Court of Justice, ruling issued the $14^{\text {th }}$ of June, 1973.

${ }^{3}$ See: Supreme Court of Justice, ruling issued the $17^{\text {th }}$ of October 2008 and Supreme Court of Justice, ruling issued the $4^{\text {th }}$ of February 2009.
} 
close to a quarter of the income (or more) of a street rebuscador. Therefore, it is unusual that street rebuscadores make contributions to the social security system, leaving them only with health-care protection provided by the subsidized health-care system. In sum, associating Rosa with the commercial sphere and with 'independent' work leaves her unprotected. Therefore, in most cases, it's not even a problem of the existence of wellintended but ineffective regulation or a problem of lack of enforcement. The real excluded just don't exist legally as workers that deserve protection because of the way categories have been framed.

\section{Street rebuscadores lack the cultural and economic capital for the adjudication of their rights to be successful}

Most street rebuscadores are self-employed. However, about one third of them are actually part of one or more bilateral employment relationships. For instance, it is common for rebuscadores to 'hire' someone to help them. Most of those workers are very young people (many of them with alcohol or drug problems), children, the elderly, homeless people and sometimes the mentally or physically disabled. According to my observations, they are paid less than half the minimum wage, if paid with money at all. They don't have the necessary skills to be precariously selfemployed, so they become part of an exploitative bilateral employment relationship very similar to that 'rejected' by some of their employers. As part of a bilateral employment relationship, workers could theoretically take legal action against their precariously self-employed employers. However, they are usually unaware of their legal rights, have very limited if any access to lawyers, and even if they did, and could overcome the common fear of losing their job, their demands are usually so small and unmanageable that the cost of enforcing them outruns any promise of benefit.

Rosa (18 years old) and Carol (21 years old) were both 'hired' by a female vendor (43 years old) to help her clean and slice the fruits and vegetables sold in the street. They were both young women with drinking problems who had to work because each of them had a child to support. Their boss used to pay them 10,000 pesos (in 2016) for a day of work, which means that they were paid less than half the minimum wage in Colombia. However, their boss described herself as belonging to that "rare type who still likes to treat people fairly". One day I was having a beer with Rosa and Carol, when Camilo (13 years old), his sister Alba (27 years old), and his sister's boyfriend Orlando ( 26 years old) arrived. Camilo felt frustrated 
because he was working in the biggest marketplace of Bogotá (Corabastos) but was being paid half el diario as compared to the other carriers. The conversation went as follows:

- Orlando: You should not complain brother (no joda hermano), you are too young and they are treating you well. I worked 15 years in abastos for a guy who paid me well but treated me like shit. When I left I wanted to sue him because I worked for him 14 hours a day and he never gave me vacations or any other legal stuff. And he treated me like shit. I really wanted to sue him because he treated me like shit. I looked for a lawyer and stuff but it was too expensive, it took too long and was too risky. I was not going to go through all that trouble of suing for my grandchildren to enjoy the money, was I?

Alba, who worked at a 'formal' job added:

- Alba: That's why I don't even think about it. I know I can work binding books in that company because I passed the physical exams.

- Laura: Exams? What type of exams?

- Alba: Physical exams. I don't have carpal tunnel syndrome yet. However, as soon as I get it, I know I will have to leave that place with nothing. Rosa and Carol heard the conversation without saying a word. I asked them what they thought about it.

- Carol: About what? Suing? I don't know. The only decent lawyer I know in the world is you... not that I know many. Plus, I wouldn't mess around with the people of abastos. No way. Plus, I don't work in anything proper or legal to think about suing. Do I?

Camilo (a youth) and Carol (a young adult with alcohol problems) are the typical workers 'hired' by other rebuscadores because they are expected to work for very low wages. Additionally, they don't represent any legal risk. This conversation shows power imbalance between the parties, but it also illustrates that both Camilo and Carol lack the cultural and economic capital required to sue their employers even though they are paid half or less the minimum wage (and they both know that a minimum wage exists). Not only they lack the economic capital required to hire a lawyer, but also the cultural capital required to know their legal rights. "I don't work in anything proper or legal to think about suing. Do I?" Carol asked me.

Orlando is not young, old, mentally or physically handicapped and has no alcohol and/or drug problems. Plus, he had a boss who owned a spot in Corabastos, which means that most likely his employer possessed more economic capital than the social base I was used to work with. Still, 
he felt he had no real incentives to sue: he had restricted access to lawyers, a lawsuit took too much time, and it could be dangerous (his boss might resort to violent means to dissuade him). Not even Alba, the only one who was in a traditional employment relationship, thought about State labour law as a way to deal with the injustices she had to deal with. As a precarious 'formal' employee she also seemed to be unaware of her legal rights, and it felt as if she already knew and accepted in advance, although not without certain resignation, her 'destiny': working until becoming ill, and then, continue working in the 'informal' sector for less money. Orlando and Alba are the 'typical' clients that lawyers discourage because their demands are too small, it is unlikely that they could win, and even if they did, it is unlikely that the decision of the judge could be enforced because employers were poor themselves. Camilo or Carol are not even discouraged by lawyers because they don't even have the amount of total capital (in Bourdieu's sense) required to know where to ask for help.

\section{The State is not interested in facilitating the enforcement of labour State law for street rebuscadores}

It's not that public officials do not want to help. On the contrary, they strongly believe that they are helping by discouraging rebuscadores to spend money they don't have in hiring a lawyer that will most likely lose the case. The State does not facilitate the enforcement of labour State law for street rebuscadores, because they are not part of the social contract. As happens with Standing's precariat, street rebuscadores have minimal trust relationships with capital or the State and none of the social contract relationships of the proletariat. They share "a sense that their labour is instrumental (to live), opportunistic (taking what comes) and precarious (insecure)" (Standing, 2011, p. 14). Welfare States as well as systems of labour regulation were built with the proletariat in mind. The proletariat consists of mostly industrial workers, for whom labour regulation regarding stability, routes of advancement, fixed hours, unionization etc., makes sense. Street rebuscadores have access to none of those social contract guarantees. By using Standing's categories, they could also be characterized as denizens: people with a more limited range of rights than citizens; disposable workers, with no access to State or enterprise benefits (Standing, 2011, p. 96).

Being excluded from the social contract is something that is not openly discussed or said. Colombia lived an internal armed conflict for more than 50 years, and one of the main arguments made by the rebels was precisely that a considerable part of the population had been historically 
excluded. The 1991 Constitution was drafted with that in mind. However, labour law remained little affected. As a matter of fact, if a street rebuscador is involved in a bilateral employment relationship, he/she can seek advice regarding employment issues at the Ministry of Labour (and no one will tell her that she is actually excluded). If she has enough information to get there, she will be sent to an 'orientation meeting' with a public official that will very likely discourage her to take legal action based on the 'particularities' of her case. In the unlikely event that the rebuscador insists, she will be sent to the Ombudsman Office (Defensoría del Pueblo) to find a public defender (because she has no money to pay for a lawyer herself). Yet, the Ombudsman Office receives only 200 people per day (people line up before sunrise to get an appointment), and a public defender will most likely refuse the case, because even if he or she won after a few years of litigation, it would be almost impossible to get a very poor employer (a rebuscador himself) to comply with the ruling and pay workers compensation fees. In sum, street rebuscadores are either excluded by de jure or de facto rights, or most likely, as a result of both.

This might appear to be just a lack of interest from the State, but there is more to it. While there is no conspiracy, it makes organizational sense for public employees to dismiss without further thought the demands of street rebuscadores, because they will not face resistance from them and will not be criticized by their superiors. According to Chambliss, public officials can stay out of trouble when they deal with the poor and socially excluded (while avoiding encounters with the powerful), because there is very little chance of bad publicity as well as criticism from their superiors (Chambliss, 1999, p. 78). Furthermore, both public officials and street rebuscadores have acquired and internalized a sense of dealing with only second-class, unthreatening citizens. Refusing or being refused seems only natural to all the parties involved. A public official from the Ministry of Labour once told me:

I understand what you mean by rebuscadores. They are not the typical kind of workers who come for legal aid, but I get what you mean. I feel bad for them. But you know we can't perform miracles. What I do is I try to listen to them. We cannot eradicate poverty, right? So I guess my job is more about listening. But I get paid for being a lawyer, not a priest or a psychologist, right? So I don't have much time. I do what I can... at least I try to make their trip worth it. That's more than most people around here do. When they leave, they are usually grateful. 


\section{Superiority of internal over external rules}

As if all of the above were not enough (labour law is rarely applicable, even when applicable street rebuscadores lack the cultural and economic capital required to be successful, and even if they do, the State is not interested in facilitating the enforcement of labour State law), the hardest obstacle for State labour law to penetrate the semi-autonomous social field of rebuscadores, is that internal rules regarding labour relations are frequently situated in relation of superior power to external rules and therefore deflect the operation of external law in the rare cases that it could apply. That should come as no surprise. As De Sousa Santos suggested more than two decades ago, the legal capital of a given legal order is not equally distributed across the legal space, and therefore each legal order has a center and a periphery (De Sousa Santos, 1987). The configurations dominant at the center (in this case, State labour law built with the proletariat in mind) tend to be taken out of the context in which they originate and exported to -or imposed upon- the periphery (where street rebuscadores are situated). The periphery is also the legal area -the "twilight zone"- where the interpenetration between different legal orders is most frequent as little attention is paid to local regulatory needs (De Sousa Santos, 1987, p. 292).

The vast majority of individuals at the periphery continue to follow customs and some of those customs are incompatible with State law. State labour law regarding stability, routes of advancement, fixed hours, unionization etc., for instance, makes no sense for self-employed rebuscadores, or even for those 'employed' by a poor rebuscador him or herself. What makes sense are survival strategies based on common unwritten customs and expectations. For example, it is expected that small children and the elderly work, helping to increase the income of the household. Camilo (13 years old), is just one of many examples. One day, while keeping me company as I was waiting for the bus, he recalled how hard he worked:

Camilo: Every day I wake up at 4 am and work as a carrier (cargo bultos) until around $10 \mathrm{am}$. Then I get back home, change and go to school to sleep (he laughs). After I leave school, I help my mother until around $9 \mathrm{pm}$, and when there is work, I take care of the cars parked near that bar. I might be getting 2 or 3 hours of sleep a day.

Section 35 of the Code of Children and Adolescents in Colombia (Law 1098 of 2006) indicates that the minimum age for work is 15 years and only exceptionally, can minor children be authorized to perform remunerated 
activities in culture, recreation, art and sports. However, Camilo's story is not uncommon. Quite to the contrary, Patricia (his mother) is a woman who raised her five kids hoping they could go to school because she couldn't.

Patricia: You know I've always tried to do my best. It was never easy... never easy... I always told them that school came first. Actually, Camilo only started working when he was eleven. I had too much pressure... my father, my mother, my brothers. We've all worked for as long as I can remember. I didn't want the same for my children. Unfortunately, his grandfather convinced him to start working because I was ill and could not produce the same diario... I had to get ill. And see? Now that he has money in his pockets, he likes it, and he's not doing well at school. My poor boy... I wish he never had to help me.

As argued before, it is also expected that homeless people, alcoholics, drug addicts as well as the mentally or physically handicapped work for very low wages, or for protection, or for a plate of food, while being frequently mistreated. In his book Sidewalk, Mitchell Duneier describes how homeless people sleep at night in the vending spot of street vendors in exchange for some money or a plate of food (Duneier, 1999). I saw the same phenomenon in Chapinero, Bogotá. A male street vendor who worked in the area told me:

Street vendor: There's always someone poorer than you. Always. For instance there is that young guy, poor guy, who is heavily using drugs. He lost his home. I don't judge, everyone carries his own burden. I help him with a few girls who work in the corner of that block (sex workers) when he takes care of our working spots. He takes really good care of us. Sometimes we give him some food, sometimes money. I know he will spend the money in drugs, but I don't judge. It's very cold at night. If I had to spend my night here I'm sure I would look for a way to get high.

Homeless people work hard for a plate of food or for a few thousand pesos. It would be difficult to prove the existence of all three elements of a labour contract in the case of the homeless person that I described above. There is a personal rendering of services, a retribution for the services (although not necessarily agreed upon previously and not necessarily in cash), and subordination (although not necessarily continuous). If the case was made that a labour contract existed, then the employer would breach the Labour Code since he is required by law to recognize all the benefits related to the employment relationship, as well as a minimum salary. It is 
highly unlikely, however, that being in breach of the Labour Code would discourage those types of informal working arrangements, since they are extremely important as part of the daily surviving strategy of those most in need.

Furthermore, street rebuscadores often don't understand what a hostile work environment is, because they are socialized in areas where violent behavior rules. They typically disregard State legislation against sexual harassment in the workplace, not only because most of its forms are deeply naturalized, but because in extreme cases the way of handling the situation has little to do with following State legal procedures. I had to witness a deeply disturbing situation while I was in Ciudad Bolívar. Most of the time women are victims of sexual harassment, but this time it was a group of young boys. A female street vendor (42 years old) 'owned' at least four different vending spots on a street. She had more economic capital than those with whom I used to work, because she was the daughter of a man who made money in dubious circumstances. She was known for 'hiring' young men to take care of her vending spots. I talked to her because I wanted to learn more about bilateral employment relationships amongst rebuscadores, but we ended up talking about something slightly different:

Vendor: I love to work with those young asses. Most women my age cannot choose, we have to live with what we get... I don't (she laughs). They know I will take good care of them if they take good care of me. There's nothing like fresh meat.

Over time, I learned that this female vendor particularly 'liked' to be found having sex with her employees to make her husband jealous. Once one of the young boys (16 years old) was severely beaten by the vendor's husband and publicly humiliated. I talked to the boy a few weeks later:

Young boy: that bitch is crazy. Crazy as hell. And that guy (the husband)... well I understand what he did. I would've done the same in his place. The guy looked for me afterwards. He doesn't care I fuck his wife. He knows I have to do it. But you know... he is a man. And she's the one with the money.

A mix of gender stereotypes and recent reconfigurations of gender roles in public spaces gave rise to that unfortunate situation. Not long before that conversation, I had written a paper about Law 1010 of 2006 which enacted measures to prevent, correct and punish harassment within the framework of labour relations in Colombia. After witnessing the events described above, it was clear to me that external legislation could not have 
the intended effects in the semi-autonomous field I was observing, because the internal ordering of the social field in which it operates is strong enough to deflect the operation of external law.

A fourthinternal rule consists in, for example, how street rebuscadores avoid minimum compliance with health and safety regulations, because they don't know about them, consider them to be unnecessary, or because they increase the cost of their survival strategies. For instance, many street rebuscadores work with food in a variety of ways (they sell fruits or vegetables, they prepare different types of food from a juice to whole meals, etc.) In Colombia, the sanitary conditions of food sales in public spaces are regulated. For instance, every person who manipulates food should wear "a blouse or apron and a cap that completely covers his or her hair. Those garments must be white and kept clean and in good condition." (Section 3 of Resolution number 604 of 1993 - Ministry of Health). Moreover, according to section 4 , he or she "must wash his hands with running water, which in any case must be drinkable, using soap, before preparing the food, before serving them, after using the toilet, after taking money, after handling raw food, or changing the activity." Furthermore, according to section 8, "the manipulator/seller must refrain from smoking, eating, coughing, spitting or sneezing on food or in the area where they are prepared." If sanitary conditions such as those described above are not satisfied, measures such as partial or total suspension of work, confiscation of objects and products, destruction of articles or products, etc., might be taken (section 15, Decree 2780 of 1991).

For street rebuscadores, however, regulations regarding sanitary conditions are seen as costly and unnecessary. After I shared some information regarding those regulations with a female street vendor who sold fruit salads on a street corner in Suba, she told me:

Those people write that stuff just to fuck with us, right? Do they even comply with all that shit in fancy restaurants? Picture me washing my hands every five minutes. It's the street assholes... the street!

In fact and not surprisingly, many street rebuscadores prefer to work in the streets, even if they would be offered a 'formal job,' because they are able to avoid State labour law. By staying where they are, their family can help them in their daily duties usually without compensation; their family can replace them during temporary or permanent absences; they are not subjected to subordination; they can express themselves freely even if that means being perceived as rude, violent or unpleasant by wealthier members of society; they can enjoy flexible hours; they can 
apply for important subsidies only available for those who are not formally employed; and finally, but most importantly, women can comply with caregiving responsibilities even if that means working for 15 or more hours a day. ${ }^{4}$ Again, that does not mean that their working conditions are desirable or even that they believe them to be desirable. It is just what they have, what they know. It is part of their habitus in Bourdieu's terms. Street rebuscadores can choose their working strategies only within a limited range of options determined by their particular trajectory in the social structure (Bourdieu, 1990). That does not mean that they cannot eventually resist (willingly or unwillingly) and act inconsistently in relation to their habitus, or even against the structures that made them, but it means that it rarely occurs. There are strong pressures to conform to their system of binding rules and customs. If adopting State labour law means disrupting the boundaries of their habitus, then most likely State labour law will not be adopted.

\section{Tutela prevails over labour disputes}

Since the tutela was created in 1991, labour disputes regarding street rebuscadores are more likely to be understood as constitutional problems and relegated to the constitutional sphere. After health care, due process, pensions and violations to the right of equality, violations related to labour conflicts are the most frequent claims litigated using the acción de tutela. In my doctoral dissertation, I described different types of tutelas filed by street rebuscadores with respect to their productive strategies. More specifically, I reviewed different cases of informal waste collectors (recyclers) seeking inclusion in the privatization process of waste management in different cities, or of rebuscadores who worked washing and watching over cars in public areas, as well as of shoeshine boys, street vendors, and others who used bicycle taxis or animal traction vehicles to make a living and survive (Porras, 2018). The common denominator in all those cases, was that the conflict was no longer between an employer and its employee, but between the precarious self-employed worker and the State. More specifically, street rebuscadores use tutelas to fight against low-level regulations governing public space affecting their different survival strategies. As César Giraldo informally suggested "the site of social struggle is no longer the conflict

\footnotetext{
${ }^{4}$ Unfortunately, the concept of 'double burden'which is used to describe the workload of people who work to earn money, but who are also responsible for significant amounts of unpaid domestic labour, does not make much sense to women who don't even know where to draw the line between labour and household work.
} 
between employer and employees." Consequently, the site of resolution of disputes has shifted from labour law to constitutional law.

Labour law does not have what it takes to translate the needs of street rebuscadores into a legal language, because most street rebuscadores are not part of a bilateral relationship of employment. The needs of street rebuscadores have been more successfully framed using the language of fundamental rights, and more specifically, the right to work and to access a minimum level of subsistence (mínimo vital). As this dissertation shows, the Colombian Constitutional Court has never considered the element of subordination when dealing with cases of street rebuscadores, at least so far. The Court assumed that street rebuscadores are workers (it never treats them as business entrepreneurs), who disserve protection, as they are part of a particular group of vulnerable citizens. Furthermore, constitutional law has also expanded our knowledge of the meaning of the collective right to maintain the integrity of public space and its limits.

That being said, in terms of access to justice, César Rodríguez wrote a chapter in abook written with Boaventura deSousa Santos where he analyzed ordinary labour justice both from the point of view of demand and supply. Regarding the demand for judicial protection in the labour jurisdiction he concluded, as expected, that there was a predominance of conflicts related to labour debts, particularly those related to compensations, social benefits and wages in traditional bilateral relations of employment. In other words, labour judges in Colombia are primarily concerned with solving a large number of repetitive micro complaints amongst the traditional parties involved in an employment relationship. Furthermore, in terms of users, the study showed a clear predominance of litigation between occasional users (workers) and frequent users (private and public companies). Most occasional users belonged to the middle class, since litigation costs are considerable for workers who belong to lower economic and occupational strata. For them, "recourse to a labour court appeared as a complicated and distant mechanism" (De Sousa Santos \& García, 2001, p. 678). All of the above, García adds, could also "explain the existence of a marked tendency towards the use of tutelas to resolve labour disputes" (De Sousa Santos \& García, 2001, p. 677). Therefore, in terms of access, street rebuscadores' access to the acción de tutela is easier (although not without complications) as compared to their only hypothetical access to labour Courts. 


\section{Strategic use of labour law}

There is one exception to State labour law's lack of penetration in the semi-autonomous social field. Street rebuscadores, who do not necessarily hope to win the legal case, use it in a strategic manner in order to demonstrate strengths through their alleged knowledge of external State legal systems. Most street rebuscadores do not know State labour law, but they have heard of it. Using the metaphor of de Sousa Santos, laws are like maps. Written laws are painted cartographic maps, and non-State laws are mental maps (De Sousa Santos, 1987). The researcher should use written maps to guide him, but he also has the duty of inquiring about the mental maps that people have in a given social field. If laws are like maps, rebuscadores identify non-State laws or the mental map of their productive strategies very well, but they have problems with painted cartographic maps (or State labour law), not only because they lack access, but because they do not possess the cultural capital required to read them appropriately (De Sousa Santos, 1987). However, they can identify loose dots, usually out of context, which they normally fill with information from their mental map, and then try to use it strategically. Most of the times, however, they are unsuccessful.

A brief anecdote can help understand my argument. Sandra, a teenage rebuscadora with alcohol problems, proudly told me once that she was able to threaten her boss (another rebuscadora who sells beer on the 'sidewalk' of a slum) with a lawsuit. The threat was as follows: if her employer did not increase her salary to around 12,000 pesos per night, then she would go to the local mayor's office and sue her for not paying mandated employment benefits, which she thought consisted of giving her food at night. The teenage rebuscadora knew that employees should have access to mandated benefits, but she was unaware of their content. Since it is common for street rebuscadores to share their food with their employees, she filled the gap with knowledge from her habitus. Her threat included filing the lawsuit at the local mayor's office, where it would probably be readily rejected without even instructing her to go to a judge. Sandra thought, however, that she was 'successful' because her employer increased her salary temporarily, only to tell her after a couple of weeks that she was not needed any more. Her employer later told me that even if Sandra was "legally right," she hated dealing with "greedy drunks."

At a more theoretical level there are certain conclusions made by legal pluralists that are corroborated by my fieldwork observations. As socio-legal life always involves interlegality, the inapplicability of State labour law is definitely compensated by the increase of local regulation. The social space 
between legislator and subject, therefore, is never a normative vacuum. The assumption that both lawyers and economists make when arguing that the informal labour market is unregulated because State labour law is either inexistent or unenforceable is empirically indefensible. However, the dialectics between legal systems develop and change over time. As of today, I gave different examples of internal rules regarding labour relations that are hierarchically superior to external rules in the semi-autonomous social field of street rebuscadores in Bogotá. That arrangement is highly dynamic, however, and could change at any time. Furthermore, there are competing, contesting, and sometimes contradictory orders outside of State law. My purpose was to describe what I consider to be general trends and agreements within the population I studied.

\section{Conclusion}

My aim was to describe the effect of labour State law on the productive strategies of street rebuscadores in Bogotá. If labour State law is unable to penetrate the semi-autonomous social field of street rebuscadores, how can we improve their lives? It is unlikely and even undesirable that street rebuscadores enter a standard employment relationship. As I discuss elsewhere, they have different incentives to continue working in the streets including higher levels of income and labour stability (as compared to the alternative types of work they could access given their social trajectory and accumulated capital), income on a daily basis (el diario), help by the family (usually children, siblings and seniors), flexible hours which allow particularly women to comply with caregiving responsibilities, possibility to apply for subsidies that are only available for the vulnerable who are not formally employed, and (most importantly) avoiding the humiliations many associate with subordination and formal employment (Porras, 2016). It is not that the working conditions are good (their daily income is merely sufficient to cover life's basic necessities, they labour excessively, their social protection rights are severely restricted, their work is usually physically and emotionally exhausting, they are heavily policed, they have no associational structure that allows them to expose their demands as a group, etc). The point is that available alternatives, even "formal jobs" can be so profoundly precarious, that one has to problematize the generalized idea that informality is bad for all workers and that formal jobs are always better. In addition, as Vosko argues, it is not even clear that we want to keep the standard relation of employment at all. This relation of employment was built on a male breadwinner/female caregiver gender contract that is 
disintegrating, union membership is dropping precipitously, it does no longer guarantee access to social wage benefits, and many workers do not aspire to hold a full-time job (Vosko, 2010, p. 312).

However, giving up on the idea that the best way to protect street rebuscadores is through a bilateral employment relationship does not mean losing some of the main benefits that have been associated so far with the existence of a bilateral employment relationship in Colombia. For instance, the social security system (health, old age, disability, survivors', sickness and maternity benefits) should be completely separated from salaried labor. In a recent book about popular economy in Colombia, Alexandre Roig and César Giraldo suggested that there is a clear dislocation between the practices of popular sectors and the devises to access social rights. Furthermore, they acknowledge that many vulnerable individuals do not aspire to be part of the proletariat, which means they do not have access to most social security benefits, although they are also particularly in need (Giraldo, 2017). In that same vein, my research shows that street rebuscadores are part of the most vulnerable population of Colombia, that they are in desperate need of social security, that it is unlikely that most of them will ever enter a standard employment relationship and that they do not have the means to contribute to the system as self-employed workers. We need to find a way to provide social security benefits to the most vulnerable, and that way is no longer by tying social security benefits to employment.

One idea that we might seriously consider is the idea of a universal basic income that takes the form of cash transfers that are universal in nature (not related to employment status). In the last decades, politicians and activists have made different proposals from very different, - even opposite- political perspectives (Barchiesi, 2007; Friedman, 1962; Gorz, 1999; Munger, 2015; Offe, 1997; Parijs, 1992; Standing, 2002; Stern, 2016). They share the common belief that a form of income should be provided by the state independently from individual employment conditions. How it could be done is heatedly debated. It is not my intention to discuss how it could be done or if it could be done (this would require another paper). Instead, I want to suggest that it is interesting that in other places of the world they are considering alternatives in the fight against poverty due to significant changes in the structure of work, and that such a debate should be seriously considered in Colombia. 


\section{Bibliographical references}

Arthurs, H. W. (1985). Without the Law: Administrative Justice and Legal Pluralism in. NineteenthCentury England. Toronto: University of Toronto Press.

Avendaño Castro, W.R. y Paz Montes, L.S. (2013). Rebusque y mendicidad: Muestra de desigualdad y pobreza en Cúcuta, Norte de Santander, Colombia. Revista Apuntes del CENES, 32 (55), 165-188. Retrieved from http://www.redalyc.org/articulo. oa? id $=479548633008$.

Barchiesi, F. (2007). South African Debates on the Basic Income Grant: Wage Labour and the Post-Apartheid Social Policy. Journal of Southern African Studies, 33 (3), 561-575. Retrieved from http://www.jstor.org/stable/25065226

Benach, J. y Muntaner, C. (2010). Empleo, trabajo y desigualdades en salud: una visión global. Spain: Icaria.

Bernal, R. (2009). The Informal Labor Market in Colombia: Identification and Characterization. Desarrollo y Sociedad, (63), 145-208. Retrieved from http://www.scielo.org.co/scielo. php?script=sci_arttext\&pid=S0120-5842009000100005\&lng=en\&tlng=.

Bernstein, S., Lippel, K., Tucker, E. \& Vosko, L. (2006). Precarious Employment and the Law's Flaws: Identifying Regulatory Failure and Securing Effective Protection for Workers. In L. Vosko (Dir.), Precarious Employment: Understanding Labour Market Insecurity in Canada (pp. 203-220). Montréal \& Kingston: McGill-Queen's University Press.

Bourdieu, P. (1990). The logic of practice (R. Nice, Trans.). Stanford, CA: Stanford University Press.

Card, D. \& Krueger, A. B. (1995). Myth and Measurement: The New Economics of the Minimum Wage. New Jersey: Princeton University Press.

Chambliss, W. L. (1999). Power, Politics \& Crime. Boulder: Westview Press.

Coraggio, J. L. (2012). La Economía Social y Solidaria (ESS) en América latina. In A. Guillén \& M. Phélan (Eds.), Construyendo el Buen Vivir (pp. 236-256). Cuenca: Universidad de Cuenca/PYDLOS.

Dakduk, S. (2008). Vivir del rebusque o vivir para rebuscarse. Debates IESA, 8(4), 7073. Retrieved from http://virtual.iesa.edu.ve/servicios/wordpress/wp-content/ uploads/2013/12/Dakduk-Vivir-del-rebusque.pdf.

Daza Pérez, J. L. (2008). Legal Determinants of Labour Informality. In J. Berg, \& D. Kucera (Ed.), In Defence of Labour Market Institutions: Cultivating Justice in the Developing World (pp. 218-233). New York, NY: International Labour Organization.

De Sousa Santos, B. (1987). Law: a Map of Misreading. Toward a Postmodern Conception of Law. Journal of Law and Society, 14(3), 279-302.

De Sousa Santos, B. (2002). Toward a New Legal Common Sense. Law, globalization, and emancipation. London: Butterworths. LexisNexis.

De Sousa Santos, B. (2004). The World Social Forum: a user's manual. Madison. Retrieved from http://www.ces.uc.pt/bss/documentos/fsm_eng.pdf.

De Sousa Santos, B. (2005). The future of the World Social Forum: the work of translation. Development, 48 (2), 15-22.

De Sousa Santos, B. \& Rodríguez, C. (2005). Law and globalization from below. Towards a cosmopolitan legality. Cambridge: Cambridge University Press.

Duneier, M. (1999). Sidewalk. New York: Farrar, Straus and Giroux.

Fitzpatrick, P. (1984). Law and Societies. Osgoode Hall Law Journal, 22(1), 115138. Retrieved from http://digitalcommons.osgoode.yorku.ca/cgi/viewcontent. cgi? article $=1946 \&$ context $=$ ohlj.

Friedman, M. (1962). Capitalism and Freedom. Chicago: University of Chicago Press. 
Galanter, M. (1974). Why the "Haves" Come out Ahead: Speculations on the Limits of Legal Change. Law and Society Review, 9(1), 95-160.

Giraldo, C. (2007). ¿Protección o desprotección social?. Bogotá D.C., Colombia: Ediciones Desde Abajo-Fundación Escuela para el Desarrollo-Universidad Nacional de Colombia.

Giraldo, C. (2016). Política Social Contemporánea: Un Paradigma en Crisis. Documento Escuela de Economía, 70. Documentos FCE-CID. Bogotá: Universidad Nacional Colombia. Recuperado de https://www.academia.edu/27814342/POL\%C3\%8DTICA_SOCIAL_ CONTEMPOR\%C3\%81NEA_Un_paradigma_en_crisis.

Gorz, A. (1999). Reclaiming Work: Beyond the Wage-Based Society. Cambridge: Polity Press.

Griffiths, J. (1986). What is Legal Pluralism?. Journal of Legal Pluralism and Unofficial Law, 18 (24), 1-55.

Kenbel, C. (2010). La ciudad desde los actores urbanos: el rebusque como modo de vida. Question, Revista especializada en periodismo y comunicación. 1 (28). Retrieved from http:// perio.unlp.edu.ar/ojs/index.php/question/article/view/1128/1006.

Marañón-Pimentel, B. (2013). La economía solidaria en México. México: Universidad Nacional Autónoma de México - Instituto de Investigaciones Económicas.

Maya, M. (2002). Las pequeñas cooperativas rurales: surge un nuevo actor económico. Economía Pública, Social y Cooperativa, 43, 85-10.

Mendoza, P. (2011). Del arte de "rebuscar" o del nuevo rostro de los trabajadores. Revista Colombiana de Sociología, 34(2), 121-136. Recuperado de https://revistas.unal.edu.co/ index.php/recs/article/view/27821/28064

Menni, A.M. (2004). Cómo rebuscársela: Trabajo informal en tiempo de crisis. Journal Política y Cultura, (25), 47-70.

Merry, S. E. (1988). Legal Pluralism. Law and Society Review, 22(5), 869-896.

Mondragón-Vélez, C., Peña, X. \& Wills, D. (2010). Labour Market Rigidities and Informality in Colombia. Documentos CEDE, 1-32.

Munger, M. (2015). Editor's Introduction. The Basic-Income Debate. The Independent Review, 19(4), 485-488. Retrieved from http://www.independent.org/pdf/tir/tir_19_04_01_ munger.pdf.

Muñoz, C. y Andrade, M. C. (2014). Las fórmulas retóricas del rebusque. Un estudio desde la semiótica social de Halliday. Tabula Rasa, (20), 329-345.

National Department of Statistics of Colombia (DANE). (2009). Metodología Informalidad Gran Encuesta Integrada de Hogares - GEIH. Diciembre 30 de 2009. Recuperado de https:// www.dane.gov.co/files/investigaciones/boletines/ech/ech_informalidad/metodologia_ informalidad.pdf.

Ochoa, D. y Ordóñez, A. (2004). Informalidad en Colombia. Causas, Efectos y Características de la Economía del Rebusque. Estudios Gerenciales, (9), 103-116.

Offe, C. (1997). Towards a New Equilibrium of Citizens' Rights and Economic Resources? In W. Michalski, R. Miller, \& B. Stevens (Eds.), Societal Cohesion and the Globalising Economy. What Does the Future Hold? (pp. 81-108). Paris: Organisation for Economic Co-operation and Development (OECD).

Parijs, P. (1992). Arguing for Basic Income: Ethical Foundations for a Radical Reform. London: Verso.

Porras, L. (2016). Reflexiones sobre la formalización del empleo como herramienta contra la pobreza. In H. Alviar e I. Jaramillo (Ed.), Perspectivas Jurídicas para la Paz (pp. 69-93). Bogotá, Colombia: Universidad de los Andes.

Porras, L. (2017). El derecho funciona más como espada que como escudo para los rebuscadores en Bogotá. In C. Giraldo (Ed.), Economía Popular desde Abajo (pp. 93.128). Bogotá D.C., Colombia: Ediciones Desde Abajo. 
Porras, L. (2018). "Viviendo del Rebusque:" A Study of How Law Affects Street Rebuscadores in Bogotá (Ph.D Thesis). University of Ottawa, Ottawa, USA.

Portes, A. (1988). La economía del rebusque. Cuadernos de Ciencias Sociales, 16.

Roig, A. (2008). El desarrollo como conflicto institucionalizado. Sumario Realidad Económica, 237, 80-92.

Standing, G. (2002). Beyond the New Paternalism: Basic Security as Equality. London: Verso.

Standing, G. (2011). The Precariat: The New Dangerous Class. London: Bloomsbury.

Stern, A. (2016). Raising the Floor: How a Universal Basic Income Can Renew Our Economy and Rebuild the American Dream. Canada: Public Affairs.

Tamanaha, B. (2000). A non-essentialist version of legal pluralism. Journal of Law and Society, 27(2), 296-321.

Teubner, G. (1997). Legal Pluralism in World Society. In G. Teubner (Ed.), Global Law without a State (pp.3-28). Dartmouth, Aldershot: Ashgate Publishing Company.

Vosko, L. (2010). Managing the margins: gender, citizenship, and the international regulation of precarious employment. Oxford: Oxford University Press. 